\title{
History of Cardiogenic Shock
}

National Cancer Institute

\section{Source}

National Cancer Institute. History of Cardiogenic Shock. NCI Thesaurus. Code C66922.

An event in the personal medical history of sustained, inadequate tissue perfusion secondary to cardiac dysfunction, generally defined as systolic blood pressure of less than $90 \mathrm{~mm} \mathrm{Hg}$ of more than 1 hour and not responsive to fluid resuscitation alone. Associated signs of peripheral hypoperfusion (e.g. cool extremities, oliguria, altered sensorium) or a cardiac index of less than $2.2 \mathrm{~L} / \mathrm{min} / \mathrm{m}^{\wedge}(2)$ are present. This clinical entity includes instances in which the systolic blood pressure is raised to $90 \mathrm{mmHg}$ or more using inotropic agents, within the first hour. (from NIH Roadmap Cardiovascular Data Standards Working Group) 